\title{
KARAKTERISTIK BAHASA KELUARGA MUDA BERDASARKAN PERBEDAAN GENDER DI KECAMATAN TUNJUNGAN KABUPATEN BLORA
}

\author{
Inna Washila Kurnianingsih \\ SMK Negeri 1 Blora, Blora, Indonesia \\ Posel : washilainna@gmail.com
}

\begin{abstract}
Language characteristics in young families cannot be separated from social situations and social interactions that exist in society. Apart from that, there are gender of language users who influence the choice of language used. The aim of this study is to analyze the characteristics of the language used in the interaction of young families in Tujungan district, Blora Regency and analyze what factors influenced other than gender differences. The data collection method used is the refer method. The data analysis method used is the extralingual equivalent method. Based on the results of data analysis, the language characteristics of young families in Tunjungan district, Blora Regency can be seen based on the gender differences which can be characterized into male and female speakers. Male language characteristics are based more on masculine traits, which are more aggressive, master of speech, brave, and fierce. The characteristics of female language are less assertive, unclear expression use figurative words more often), and careful in saying something. Factors that influence language choice in young family interactions other than gender differences are ethics / social norms, level of familiarity, speech situation, speech topic, and location of speech.
\end{abstract}

Keywords: language choice, young family, gender

\begin{abstract}
Abstrak : Karakteristik bahasa dalam keluarga muda tidak dapat terlepas dari situasi sosial dan interaksi sosial di masyarakat. Terlepas dari hal itu, terdapat gender pengguna bahasa yang turut memengaruhi pilihan bahasa yang digunakan. Tujuan penelitian ini untuk menganalisis karakteristik bahasa yang digunakan dalam interaksi keluarga muda di Kecamatan Tujungan Kabupaten Blora dan menganalisis apa saja faktor pengaruh selain faktor perbedaan gender. Metode pengumpulan data yang digunakan adalah metode simak. Metode analisis data yang digunakan adalah metode padan ekstralingual. Berdasarkan hasil analisis data, karakteristik bahasa keluarga muda berdasarkan perbedaan gender di Kecamatan Tunjungan Kabupaten Blora dapat dilihat berdasarkan karakteristik penutur laki-laki dan perempuan. Karakteristik bahasa laki-laki lebih didasarkan pada sifat maskulin, yaitu lebih agresif, menguasai pembicaraan, berani, dan garang. Adapun karakteristik bahasa perempuan bersifat kurang tegas, tidak mengutarakan secara jelas (lebih sering memakai kata kiasan), dan berhati-hati dalam mengucapkan sesuatu. Faktor yang memengaruhi pilihan bahasa dalam interaksi keluarga muda selain faktor perbedaan gender adalah etika/norma sosial, tingkat keakraban, situasi tutur, topik tuturan, dan lokasi tuturan.
\end{abstract}

Kata Kunci : pilihan bahasa, gender, keluarga muda. 


\section{Pendahuluan}

Keberadaan bahasa merupakan kelebihan yang dimiliki manusia dibanding dengan makhluk lain yang ada di dunia. Bahasa merupakan hasil konsensus bersama antarmanusia yang kini menduduki peran penting dalam bagian kehidupan manusia. Sebagai hasil konsensus bersama atau hasil karya yang dihasilkan, bahasa dapat dikategorikan sebagai unsur kebudayaan yang bersifat universal. Artinya, bahasa merupakan unsur kebudayaan yang pasti dapat ditemukan di semua daerah, baik yang di pedesaan kecil terpencil maupun di perkotaan yang besar dan kompleks (Koentjaraningrat, 1994:2). Bahasa juga dipandang sebagai sistem sosial dan sistem komunikasi yang merupakan bagian dari masyarakat dan kebudayaan (Greenberg dalam Suwito, 1985:2).

Sebagai bagian masyarakat, manusia ditakdirkan lahir sebagai makhluk sosial. Manusia senantiasa membutuhkan manusia lain untuk memenuhi kebutuhan sosialnya. Interaksi sosial yang terjadi antarmanusia secara tidak langsung juga akan berpengaruh terhadap keberadaan bahasa. Hal ini terjadi karena kegiatan tersebut akan melibatkan beberapa orang dengan latar belakang bahasa yang berbeda, sehingga akan menimbulkan adanya interaksi bahasa dan mendorong terjadinya variasi dalam pemakaian bahasa. Hal ini pula yang pada akhirnya mendorong manusia untuk melakukan suatu pilihan bahasa. Dalam kehidupan, pilihan bahasa juga dipandang sebagai peristiwa sosial yang berkembang di masyarakat.

Pilihan bahasa merupakan sesuatu yang dipandang sebagai masalah yang dihadapi masyarakat yang tinggal di antara interaksi dua bahasa atau lebih. Dengan adanya interaksi dua bahasa atau lebih yang ada di masyarakat, hal ini akan mendorong manusia untuk menentukan sikap bahasa. Terdapat tiga jenis pemakaian bahasa yang dikaji dalam sosiolinguistik, yaitu alih kode, campur kode, dan variasi dalam bahasa yang sama (Sumarsono, 2004:201).

Alih kode merupakan gejala peralihan pemakaian bahasa sebagai akibat adanya perubahan situasi tutur. Campur kode merupakan gejala peralihan pemakaian bahasa yang terjadi akibat penutur bahasa menyelipkan unsur bahasa lain ketika sedang memakai bahasa tertentu. Variasi dalam bahasa yang sama merupakan jenis pilihan bahasa yang menentukan adanya sikap bahasa pada seseorang. Ketiga pilihan bahasa tersebut dapat dianggap mudah ditentukan dan dapat juga diaggap sukar ditentukan. Hal ini terjadi karena batasan di antara pilihan bahasa tersebut seringkali berubah menjadi kabur.

Untuk menganalisis pilihan bahasa yang dipakai manusia, gaya bahasa menjadi unsur yang penting keberadaannya. Keraf (2007:113) menyatakan bahwa gaya bahasa merupakan cara untuk mengungkapkan pikiran melalui bahasa secara khas yang memperlihatkan jiwa dan kepribadian penulis. Dengan demikian, akan ditemukan perbedaan antara gaya pilihan bahasa laki-laki dan perempuan. Perbedaan tersebut bukan hanya sebatas akibat perbedaan kelamin saja, melainkan terdapat gender atau konsep sosial yang membedakan antara peran laki-laki dan perempuan yang memberikan sekat perbedaan yang lebih kompleks.

Perbedaan gender pengguna bahasa merupakan salah satu faktor yang menarik perhatian. Bagaimana bisa suatu gender memengaruhi pilihan bahasa cukup menarik untuk diteliti. Apalagi dalam kehidupan banyak isu berkembang mengenai diskriminasi gender yang ada di masyarakat. Banyak orang beranggapan bahwa gender dan sex itu sama dan didefinisikan sebagai perbedaan jenis kelamin. Namun, pendapat tersebut sebenarnya tidak tepat. Menurut Handayani (2008:4)sex adalah pembagian jenis kelamin secara biologis, melekat pada jenis kelamin tertentu. Hal ini berarti bahwa sex hanya membedakan antara jenis kelamin laki-laki dan perempuan yang secara kodrati masing-masing memiliki fungsi organisme yang berbeda.

Berbeda halnya dengan sex, gender lebih sering diartikan sebagai konsep sosial yang membedakan antara peran laki-laki dan 
perempuan. Gender merupakan sifat yang melekat pada kaum laki-laki dan perempuan yang dibentuk oleh faktor-faktor sosial dan budaya antara laki-laki dan perempuan. Bentukan sosial antara laki-laki dan perempuan adalah perempuan dikenal sebagai makhluk lemah lembut, cantik, sentimentil, emosional, dan keibuan. Adapun lelaki dianggap kuat, rasional, jantan, dan berani (Handayani, 2008:5).

Dalam interaksi sosial yang ada di masyarakat, seringkali perempuan menduduki posisi kedua setelah laki-laki. Pernyataan ini dikuatkan oleh pendapat Sumarsono (2004:98) yang menyatakan bahwa wanita selalu diletakkan di nomor dua dan sering tidak dipakai dalam penelitian linguistik karena dipengaruhi oleh sikap "hiperkorek" yang ditakutkan dapat mengaburkan situasi sebenarnya yang diinginkan oleh peneliti.

Perbedaan antara laki-laki dan perempuan tersebut dapat berupa perbedaan sikap, cara pandang, dan juga cara berbahasa dalam kehidupan sehari-hari. Perempuan dianggap dapat menempatkan diri dalam pembicaraan dan cenderung menggunakan bahasa yang lebih sopan dibanding laki-laki. Kurath (dalam Sumarsono, 2004:98) mengemukakan:

"... they should be male because in the Western nations women's speech tends to be more self-conscious and classconsious than men's..."

'...mereka, yaitu responden haruslah laki-laki karena dalam masyarakat barat tutur wanita itu cenderung lebih sadar-diri dan sadar-kelas daripada tutur laki-laki...'

Pendapat di atas menguatkan anggapan bahwa memang benar terdapat perbedaan antara laki-laki dan perempuan dalam pemakaian bahasa untuk berkomunikasi.

Sebagai makhluk sosial, baik laki-laki maupun perempuan akan menjalani fase kehidupan berkeluarga. Keluarga merupakan tempat pertama dan utama bagi anak untuk membentuk kepribadian dan mencapai tugas perkembangannya (Gerungan, 1996:6). Keluarga adalah lingkungan awal yang mengajarkan bahasa kepada anak sebelum nantinya dapat belajar dari dunia luar. Bahasa pertama yang diajarkan kepada anak biasanya lebih dikenal sebagai bahasa daerah (bahasa ibu). Selain lingkungan keluarga, lingkungan tempat tinggal dan lingkungan sekolah juga turut memberikan andil terhadap perkembangan bahasa pada seorang anak.

Chaer (2004:204) menyatakan bahwa lingkungan keluarga, lingkungan masyarakat tempat tinggal, dan lingkungan sekolah sangat berperan dalam pembelajaran bahasa seseorang. Dengan demikian, ketika anak sudah mampu berinteraksi dengan dunia luar dan mulai mempelajari bahasa lain, maka anak tersebut dapat dikategorikan sebagai dwibahasawan. Dwibahasawan merupakan orang yang dalam interaksi sosialnya dapat menggunakan lebih dari satu bahasa, misal bahasa daerah, bahasa Indonesia, dan bahasa Asing (Alwasilah, 1993:144).

Sebagai seorang dwibahasawan, masyarakat akan dihadapkan dengan permasalahan pilihan bahasa. Pilihan bahasa tersebut akan mendorong seseorang untuk menentukan sikap bahasanya. Ini pula yang dihadapi masyarakat yang tinggal di Kecamatan Tunjungan Kabupaten Blora. Sebagai dwibahasawan, masyarakat di daerah tersebut akan dihadapkan pada pilihan bahasa yang akan digunakan dalam interaksi sosial dengan masyarakat lain. Terlebih masyarakat di daerah tersebut bersifat heterogen yang masing-masing memiliki latar belakang kehidupan yang berbeda.

Terdapat tiga jenis pilihan bahasa yang dapat digunakan dalam kajian sosiolinguistik. Pertama, alih kode (code switching), artinya gejala peralihan kode bahasa sebagai akibat berubahnya situasi tutur (Sumarsono, 2004:202). Alih kode dapat menduduki fungsi sosial karena alih kode berusaha menyesuaikan pilihan pemakaian bahasa sesuai dengan lawan tutur dalam berbicara. Hymes (dalam Chaer, 2004:107) menambahkan bahwa alih kode bukan hanya berkaitan dengan peralihan antarbahasa, tetapi juga terjadi antara ragam bahasa atau gayagaya yang terdapat dalam satu bahasa. 


\section{Metode Penelitian}

Penelitian ini menggunakan pendekatan teoretis dan pendekatan metodologis. Pendekatan teoretis yang digunakan dalam penelitian ini adalah pendekatan sosiolinguistik, yaitu pendekatan penelitian yang berkaitan dengan ilmu penggunaan bahasa dalam kaitannya dengan masyarakat.

Pendekatan metodologis yang digunakan dalam penelitian ini adalah pendekatan deskriptif kualitatif. Pendekatan deskriptif merupakan pendekatan penelitian yang semata-mata berdasarkan pada fakta yang ada pada penutur bahasa. Penelitian ini tidak mempertimbangkan benar ataupun salahnya penggunaan bahasa oleh penuturnya (Sudaryanto, 1993:62).

Penelitian deskriptif kualitatif dalam penelitian ini adalah prosedur penelitian dengan hasil sajian data deskripsi berupa wujud kode bahasa dan peran gender dalam pemilihan bahasa pada interaksi keluarga muda yang terdapat di Kecamatan Tunjungan Kabupaten Blora.

Lokasi penelitian terletak di Kecamatan Tunjungan Kabupaten Blora. Kecamatan Tunjungan terbagi atas 15 desa, yaitu desa Adirejo, Gempolrejo, Kalangan, Kedungrejo, Kedungringin, Keser, Nglangitan, Sambongrejo, Sitirejo, Sukorejo, Tamanrejo, Tambahrejo, Tawangrejo, Tunjungan, dan Tutup. Kecamatan Tunjungan memiliki luas daerah 10.338,6 $\mathrm{km}^{2}$ dan jumlah penduduk sebanyak 43.651 jiwa.

Kecamatan Tunjungan Kabupaten Blora dipilih karena bahasa yang digunakan untuk berkomunikasi oleh masyarakat Blora memiliki kekhasan tersendiri yang tidak ditemukan di daerah lain. Kekhasan yang dimaksud adalah kekhasan dari segi leksikal, fonologis, dan sintaksis. Dari segi leksikal, kekhasan bahasa yang digunakan untuk berkomunikasi oleh masyarakat Blora dapat dilihat dari adanya beberapa kata yang hanya dijumpai di daerah Blora, misalnya kata njongok [njōo?] 'duduk' dan mbalik [mbalI?]'pintar'.
Berdasarkan segi fonologis, kekhasan bahasa yang digunakan untuk berkomunikasi oleh masyarakat Blora terlihat pada vokal bahasanya. Penggunaan vokal bahasa Jawa oleh masyarakat Blora seringkali mengalami perubahan bunyi akhir seperti yang terlihat pada penggunaan kosakata putih [putch] 'warna putih' dan gurih[gurEh] 'lezat/ gurih'. Berdasarkan segi sintaksis, kekhasan bahasa yang digunakan untuk berkomunikasi oleh masyarakat Blora dapat terlihat pada penggunaan enklitik $\{$-em $\}$ untuk menyatakan kepemilikan seperti yang terlihat pada kata omahem[omahəm] 'rumahmu'.

Data merupakan hasil pencatatan penelitian yang berupa kosakata maupun kalimat yang dapat dijadikan sebagai sumber informasi (Mahsun, 2007:18). Data dalam penelitian ini berupa kata, frasa, kalimat yang terdapat dalam tuturan keluarga muda di Kecamatan Tunjungan Kabupaten Blora.

Sumber data dalam penelitian ini adalah semua tuturan lisan dalam interaksi keluarga muda di Kecamatan Tunjungan Kabupaten Blora. Keluarga muda dipilih karena diyakini mampu terbuka dengan dunia luar sehingga kontak bahasa yang mereka lakukan pun lebih bervariatif.

Pengumpulan data adalah pencatatan peristiwa atau hal-hal yang mendukung atau menunjang penelitian (Moleong, 2004:83). Adapun metode pengumpulan data yang digunakan dalam penelitian ini adalah metode simak. Dalam praktiknya, metode simak terbagi atas teknik simak libat cakap, teknik simak bebas libat cakap, teknik rekam, dan teknik catat.Teknik simak libat cakap digunakan untuk mendapatkan data berupa tuturan langsung dengan cara si peneliti terlibat langsung dalam suatu percakapan. Teknik simak bebas libat cakap digunakan untuk mengetahui tuturan keluarga muda di lokasi penelitian. Teknik rekam digunakan untuk memperkecil kemungkinan hilangnya informasi dari penutur. Teknik rekam dilakukan atau diatur agar tidak diketahui oleh penutur (informan) supaya tidak memengaruhi kewajaran tuturan. 
Teknik catat dilakukan terhadap kata, frasa, atau kalimat yang diutarakan oleh anggota keluarga muda di Kecamatan Tunjungan Kabupaten Blora. Data-data yang diperoleh nantinya akan dicatat dalam kartu data untuk memudahkan proses analisis yang akan dilakukan.

Metode analisis data yang digunakan dalam penelitian ini adalah metode padan. Metode padan merupakan metode analisis data yang dilakukan dengan menghubungbandingkan antarunsur yang bersifat lingual (Mahsun, 2007:259). Terdapat dua jenis metode padan dalam penelitian kualitatif, yaitu padan intralingual dan padan ekstralingual. Padan intralingual merupakan metode analisis dengan cara menghubungbandingkan unsur-unsur yang bersifat lingual, baik yang terdapat dalam suatu bahasa maupun dalam beberapa bahasa yang berbeda.

Padan ekstralingual merupakan metode analisis yang bersifat ekstralingual. Metode ini menghubungkan masalah bahasa dengan hal-hal yang diluar bahasa, seperti referen, konteks tuturan: konteks sosial pemakaian bahasa, penutur bahasa yang dipilah misalnya berdasarkan gender, usia, kelas sosial, dan sebagainya (Mahsun, 2007:260).

Penelitian ini menggunakan metode padan ekstralingual untuk menganalisis data.Peneliti memilih menggunakan metode tersebut karena peneliti hendak menganalis data dengan cara menghubungkan masalah bahasa dengan hal-hal yang berada di luar bahasa, seperti referen dan konteks sosial pemakaian bahasa.

Dalam penelitian bahasa terdapat dua metode penyajian data, yaitu metode formal dan metode informal. Metode formal adalah perumusan dengan tanda-tanda atau lambang (Sudaryanto, 1993:145). Metode informal adalah penyajian data dengan kata-kata. Dalam penelitian ini, peneliti memilih menggunakan metode penelitian informal.

\section{Hasil dan Pembahasan}

Bahasa merupakan bagian dari kebudayaan yang berkembang dalam masyarakat. Tiap bahasa yang digunakan untuk berkomunikasi masyarakat memiliki karakteristik tersendiri. Karakter-karakter dalam berbahasa dapat terbentuk dari kondisi siosial masyarakat yang ada, sistem nilai sosial yang berlaku, dan perbedaan gender pengguna bahasa. Karakter berbahasa seseorang dapat terbentuk karena adanya perbedaan gender antara pengguna bahasa. Dengan demikian, dapat dikatakan bahwa bahasa mampu merefleksikan perbedaan pandangan dan penilaian masyarakat atas bahasa seperti apa yang pantas bagi laki-laki dan perempuan. Berikut ini akan dipaparkan perbedaan penggunaan bahasa antara laki-laki dan perempuan yang terjadi pada interaksi keluarga muda di Kecamatan Tunjungan Kabupaten Blora.

\section{Karakteristik Bahasa Laki-Laki}

Bahasa merupakan alat komunikasi massa yang mampu merekam asumsi mengenai bagaimana seorang laki-laki berperilaku. Terlebih dalam masyarakat yang masih mengenal adanya sistem patriarki, yaitu posisi laki-laki akan diletakkan menjadi lebih tinggi dibanding posisi perempuan. Hal ini akan melahirkan pandangan mengenai perbedaan posisi antara laki-laki dan perempuan yang berakibat penggunaan bahasa di antara keduanya. Perbedaan penggunaan bahasa yang dimaksud bukan hanya terletak pada perbedaan suara, pemakaian gramatika, pilihan kata, tetapi juga mengenai cara penyampaian bahasa.

Bahasa yang digunakan untuk berkomunikasi antara laki-laki dan perempuan terbukti memiliki perbedaan tersendiri, perbedaan ini dapat terbentuk karena adanya interaksi sosial, nilai-nilai sosial, peran sosial yang ada, dan karena adanya budaya yang berbeda antara laki-laki dan perempuan. Dalam berbahasa, laki-laki lebih didasarkan pada sifat maskulin, yaitu lebih agresif, berani, dan garang. Adapun contoh percakapan yang akan mewakili sifat-sifat laki-laki dalam berbahasa akan tergambar pada kutipan percakapan berikut ini.

(1)KONTEKS: PUNGGUH MEMBERIKAN TANGGAPAN MENGENAI 
PEMBERITAAN DI TELEVISI YANG

MEMUAT BERITA PERNIKAHAN
CRISTY JUSUNG

Pungguh: "Cristy Jusung entuk bojo wong tuwek gelem ae."

[Crsty Jusung ontU? bojo woๆ tuwE? gələm ae]

'Cristy Jusung mendapatkan suami tua mau saja'

Mbak Rini: "Sugeh og."

[sugEh og]

'soalnya kaya sih'

Pungguh : "Maune bojone sapa eh?"

[Maune bojone sopo $\mathrm{Eh}$ ]

'Tadinya suaminya siapa ya?'

Nia : "Hengki Kurniawan."

Pungguh : "Aluwung entuk tuwek ndang matek."

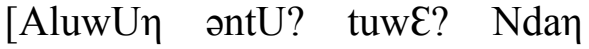
matE?]

'Lebih baik dapat tua, cepat meninggal'

MbakRini:"Ndang entuk warisan ya? hahaha"

[Ndaך əntU? warIsan yo. hahaha]

'Cepat dapat warisan ya, hahaha'

Pungguh: "Iya. Timbangane nom trus do selingkuh rak alung tuwek-tuwek. Jongkrokno ndredek-ndredek, sentak sitik watuke njeglik."

[iyo, tImbanane nom trUs do

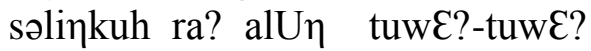
jəฤkrə?n ndrəde?-ndrədə?, sənta? siţI? watUke njəglI?]

'Iya, daripada suaminya muda terus pada selingkuh, lebih baik yang tua saja. Didorong langsung gemetar, diteriaki sedikit langsung batuk-batuk.

(Data 4)

Dalam bahasa yang digunakan dalam berkomunikasi biasanya memiliki nilai konotasi yang berbeda-beda, dan biasanya laki-laki memilih berbahasa dengan menggunakan konotasi kasar. Seperti contoh tuturan (23) tampak bahwa penutur laki-laki terlihat lebih berani dan agak kasar. Ini tampak pada dialognya yang berbunyi "Aluwung entuk tuwek ndang matek,"'lebih baik dapat suami tua, cepat meninggal'. Dari kata tersebut tampak bahwa penutur memiliki keberanian dalam berkomunikasi. Tuturan yang dikatakan penutur dapat dikategorikan sebagai kata-kata sumpah serapah kepada objek yang dibicarakan. Kata lain yang juga memberikan gambaran tentang keberanian penutur dalam memilih kosakata yang kasar juga tampak pada tuturan "Iyo. Timbangane nom trus do selingkuh rak alung tuwek-tuwek. Jongkrokno ndredek-ndredek, sentak sitik watuke njeglik". Meski pembicaraan yang dilakukan oleh penutur dan mitra tutur terdapat nilai humornya, namun tetap saja penutur memilih menggunakan pilihan kata yang memiliki konotasi lebih kasar seperti yang terlihat pada kalimat "Aluwung entuk tuwek ndang matek", "Iyo. Timbangane nom trus do selingkuh rak alung tuwek-tuwek. Jongkrokno ndredek-ndredek, sentak sitik watuke njeglik".

Contoh kutipan lain yang juga menunjukkan perbedaan pilihan penggunaan bahasa yang digunakan laki-laki akan tanpak pada kutipan berikut ini.

(2)KONTEKS: NURI MEMANGGIL PAK SUS UNTUK IKUT BERGABUNG DUDUK BERAMAI-RAMAI.

Nuri: "He, Pak Sus sini-sini."

Rian: "Mriki-mriki gabung sekalian."

[Mriki-mriki gabuך səkalian]

'Sini-sini sekalian bergabung'

Nuri: "Pak Sus ayo rene. Ayo ning kene"

[Pak Sus ayo rene. Ayo nI $\eta$ kene]

'Pak Sus ayo kesini. Ayo di sini saja'

Atik: "Kersane nglumpuk"

[kərsane ๆlumpU?]

'Supaya berkumpul'

Nuri: "Pak Sus, tak banting lho nek gak gelem rene."

[pak Sus, ta? bantI $\eta$ lho nE? Ga? gələm rene]

'Pak Sus, saya banting tho nanti kalau tidak mau kesini'

(Data 37)

Pada tuturan (25) merupakan tuturan yang dilakukan dalam interaksi keluarga 
muda. Nuri dan Atik merupakan pasangan keluarga muda yang usia pernikahannya sudah memasuki tahun ke-3. Dalam interaksi keluarga muda tersebut tampak bahwa tuturan yang dilakukan Nuri lebih terkesan memaksa dan tidak sabaran. Hal ini terlihat pada tuturannya yang kembali diulang-ulang untuk mengajak Pak Sus agar mau duduk dengannya. Selain terkesan memaksa dan tidak sabar, tuturan yang diucapkan Nuri juga mengandung kosakata yang agak kasar. Ini tampak pada tuturan Nuri ketika berkata "Pak Sus, tak banting lho nek gak gelem rene". Kata "tak banting" yang diucapkan Nuri dimaksudkan agar Pak Sus mau mengikuti ajakan Nuri. Kata tersebut memiliki konotasi yang kasar meskipun pada penggunaannya Nuri memilih kata tersebut hanya sebatas untuk bergurau terhadap Pak Sus dan bukan berupa suatu ancaman.

Pemilihan kosakata yang cenderung kasar dan berani tidak serta merta dilakukan begitu saja oleh penutur. Penutur yang memiliki hubungan sosial dengan orangorang yang terbiasa berbicara dengan kosakata kasar, agresif, dan berani akan cenderung memiliki keberanian untuk menggunakan kosakata yang kasar pula. Ini pula yang dialami oleh penutur dalam contoh kutipan percakapan sebelumnya. Akibat kontak sosial dengan masyarakat luas yang masing-masing memiliki latar belakang pendidikan dan sosial yang berbeda, menjadikan penutur tidak segan menggunakan kosakata yang cenderung kasar dalam berkomunkasi.

\section{Karakteristik Bahasa Perempuan}

Berbicara mengenai perempuan tidak dapat terlepas dari adanya stigma yang menyebutkan bahwa perempuan pada dasarnya mewarisi sifat lemah lembut dan penyayang. Dengan alasan tersebut, maka muncul anggapan bahwa dalam berbahasa seorang perempuan dipengaruhi kedua sifat dasarnya tersebut. Dan benar saja, kedua sifat dasar yang diwarisi perempuan sejak lahir memang memberikan sumbangan mengenai penggunaan bahasanya.
Bahasa yang digunakan perempuan bersifat kurang tegas, tidak mengutarakan secara jelas (lebih sering memakai kata kiasan), dan berhati-hati dalam mengucapkan sesuatu. Dalam berbicara, perempuan juga lebih sering membicarakan orang lain, mudah bersimpati, dan menceritakan hubungan sosialnya dengan orang lain. Adapun contoh percakapan yang akan mewakili sifat-sifat perempuan dalam berbahasa akan tergambar pada kutipan percakapan berikut ini.

\section{(3)KONTEKS: MBAK ELI (SEORANG IBU MUDA) MEMANGGIL ANAKNYA YANG BERUSIA 2,5 TAHUN YANG SEDANG BERMAIN DI LUAR RUMAH}

\author{
Mbak Eli : "Hey Sya sini lho. Nanti nek kamu \\ ditemok orang lho. Ayo sini! \\ [Hey Sya sini lho. Nanti ne? Kamu \\ dItəmo? oran lho. Ayo sini!] \\ 'Hey Sya sini lho. Nanti kalau \\ kamu dibawa orang lho. Ayo \\ sini!' \\ (Data 1)
}

Dalam percakapan di atas tampak bahwa penutur sedang meminta anaknya yang masih kecil untuk kembali masuk rumah. Pada kutipan tuturan tersebut tampak bahwa seorang ibu menggunakan bahasa yang santai dan tidak memiliki konotasi keras terhadap anaknya. Selain itu, ibu muda ini juga memilih menggunakan kata "ditemok" untuk menakuti anaknya agar mau masuk ke rumah. Dalam bahasa Indonesia, kata "ditemok" dapat disepadankan dengan kata 'ditemukan'. Berbeda dengan kata "ditemok" yang digunakan ibu muda pada tuturan tersebut sebenarnya bukan mengacu pada makna sebenarnya, melainkan mengacu pada kata "diculik". Kata "ditemok" dipilih untuk menggantikan kata "diculik" karena penutur menganggap mengungkapkan kata "diculik" kepada anaknya merupakan sesuatu yang dianggap tabu.

Dengan demikian, tuturan tersebut membuktikan bahwa dalam berbahasa, seorang perempuan kadang memilih 
menggunakan kata kias (kata yang bermakna tidak sebenarnya) untuk menghindari hal-hal yang dianggap tabu untuk diucapkan.

Contoh kutipan lain yang juga menunjukkan perbedaan pilihan penggunaan bahasa yang digunakan perempuan akan tampak pada kutipan berikut ini.

(4)KONTEKS: IBU RUMINA BERTANYA KEPADA NIA TENTANG SEBAB NIA YANG SUDAH PULANG KE RUMAH LAGI

Ibu Rumina: "Lho, Mbak Nia kok sampun nyapu di rumah, kapan wangsule?"

[lho, Mbak Nia ko? sampUn nyapu d rumah, kapan wansUle]

'Lho Mbak Nia kok sudah menyapu di rumah lagi? Kapan pulangnya?

Nia : "Kemarin Tante."

Ibu Rumina : "Nembe liburan apa Mbak?"

[Nəmbe liburan apa, Mbak]

'Lagi liburan ya, Mbak?'

$\mathrm{Nia}$

: "Nglibur. Hahaha"

[nllbur. hahaha]

'Bolos, hahaha'

(Data 10)

Dalam tuturan di atas juga ditemukan bahwa Nia memilih menggunakan kata "nglibur" untuk menggantikan kata "bolos". Kata "nglibur" dinilai memiliki nilai rasa yang lebih tinggi daripada kata "bolos" meskipun pada dasarnya keduanya sama-sama berarti tidak masuk sekolah. Selain ditemukan kata tersebut, dalam tuturan tersebut juga tampak bahwa kedua perempuan yang terlibat dalam tuturan menggunakan bahasa yang sopan. Tidak ditemukan kata yang cenderung bermakna kasar dalam tuturan tersebut. Ini membuktikan bahwa dalam berkomunikasi perempuan memilih menggunakan bahasa yang lebih sopan dengan tujuan untuk menunjukkan kesetaraan dan keharmonisan hubungan di antara keduanya.

Berdasarkan kutipan-kutipan tuturan yang terjadi pada interaksi keluarga muda di
Kecamatan Tunjungan Kabupaten Blora tampak bahwa penutur perempuan lebih memilih menggunakan bahasa yang memiliki nilai rasa yang sopan dan terlihat lebih berhati-hati untuk menjaga perasaan mitra tuturnya. Hal ini tampak pada tuturan penutur perempuan yang kadangkala memilih menggunakan kata kias dalam tuturan untuk mengungkapkan sesuatu.

\section{Faktor yang Memengaruhi Karakteristik Bahasa dalam Interaksi Keluarga Muda di Kecamatan Tunjungan Kabupaten Blora Selain Faktor Perbedaan Gender}

Faktor sosial yang terdapat dalam interaksi sosial masyarakat memang tidak dapat dilepaskan dari aktivitas berbahasa. Oleh karena itu, tidak aneh apabila dalam kegiatan berbahasa sangat dipengaruhi oleh latar belakang sosial penutur. Seperti halnya yang dialami oleh masyarakat dalam keluarga muda di Kecamatan Tunjungan Kabupaten Blora. Selain ditentukan oleh faktor perbedaan gender, terdapat faktor-faktor lain yang turut memengaruhi pilihan kode masyarakat disana. Adapun faktor lain yang turut memengaruhi pilihan bahasa pada peserta tutur dalam keluarga muda di Kecamatan Tunjungan Kabupaten Blora adalah etika/norma sosial, tingkat keakraban, situasi tutur, topik tuturan, dan lokasi tuturan.

\section{Etika/ Norma Berbahasa}

Etika/ norma merupakan salah satu faktor yang memengaruhi pilihan kode bahasa. Etika berbahasa memegang peranan penting dalam proses komunikasi. Etika berbicara akan menuntun kita untuk menentukan kode bahasa apa yang cocok digunakan ketika berbicara dengan lawan tutur.

Pada penelitian tentang pilihan bahasa pada tuturan keluarga muda di Kecamatan Tunjungan Kabupaten Blora, etika berbicara merupakan salah satu faktor yang memiliki pengaruh besar dalam pemilihan kode bahasa. 
Volume 1, Nomor 1, Januari 2019

ISSN 2655-3031 (P)

ISSN 2655-7851 (O)

Etika/ norma berbahasa dalam bahasa Jawa akan tampak pada pilihan kosa kata, terlebih dalam bahasa Jawa terdapat tingkatan dalam berbahasa. Tingkatan dalam berbahasa Jawa yang dimaksud adalah penggunaan ragam bahasa Jawa ngoko dan krama.

Dalam bertutur kata, masyarakat yang memegang teguh norma dalam bahasa Jawa akan sangat berhati-hati dalam berbahasa. Pemilihan kosakata yang tepat akan sangat menentukan penilaian dari mitra tutur terhadap sikap penutur. Oleh karena itu, kebanyakan masyarakat yang tinggal di Jawa masih memegang teguh norma, yakni dengan cara tetap mempertimbangkan kepada siapa dia bertutur dan ragam bahasa apa yang paling tepat dipilih.

Masyarakat tutur pada keluarga muda di Kecamatan Tunjungan menganut dua kode pilihan bahasa, yaitu bahasa Indonesia dan bahasa Jawa. Bagi penutur yang memiliki hubungan yang kurang dekat dengan mitra tuturnya akan cenderung memilih menggunakan bahasa Jawa ragam krama dan bahasa Indonesia. Hal ini dilakukan untuk menunjukkan rasa menghormati kepada lawan bicaranya. Seperti contoh percakapan berikut ini yang terjadi antara Yuni dan Seorang pengendara motor yang bertanya tentang arah menuju rumah Pak Bayu.

(5)KONTEKS: YUNI MEMBERIKAN PENJELASAN KEPADA SESEORANG MENGENAI ARAH MENUJU RUMAH PAK BAYU

Pengendara: "Nyuwun sewu, Mbak. Nderek tanglet. Dalemipun Pak Bayu meniko ingkang pundi nggih, Mbak?",

[थ̃uwUn sEwu, Mba?. NdErE? taךlət. Daləmipun Pa? Bayu

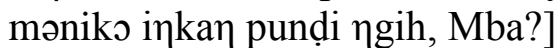
'Permisi, Mbak. Numpang bertanya. Rumahnya Pak Bayu itu yang sebelah mana ya, Mbak?'

Yuni : "Niki sakmeniko njenengan lurus mawon, Pak. Mangke wonten masjid, lha ngajengipun masjid pas meniko dalemipun Pak Bayu."

[NikI sakməniks njənəฤan lurus mawon, Pa?. Maףke wontən

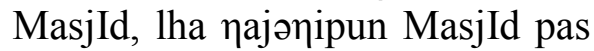
məniko daləmipun Pak Bayu."

'Dari sini Bapak lurus saja. Nanti ada Masjid, nah tepat di depan Masjid itu rumah Pak Bayu.'

Pengendara : "Oh, Nggih mpun, Mbak. Matur suwun."

[oh, ๆgih mpUn, Mbak. Matur suwun.]

'Oh, iya, Mbak. Terimakasih.'

(Data 29)

Pada tuturan (29) tampak bahwa penutur dan mitra tutur sama-sama menggunakan bahasa Jawa ragam krama untuk berkomunikasi. Ini terjadi karena penutur dan mitra tutur tidak saling mengenal dan belum pernah bertemu sebelumnya. Untuk menunjukkan rasa menghormati dan menghargai kepada lawan bicaranya, maka baik penutur maupun mitra tutur memilih untuk menggunakan bahasa Jawa ragam krama.

Tuturan bermula ketika ada seorang pengendara yang berhenti dan kemudian bertanya kepada Yuni dengan berkata "Nyuwun sewu, Mbak. Nderek tanglet. Dalemipun Pak Bayu meniko ingkang pundi nggih, Mbak?". Berdasarkan tuturan tersebut tampak bahwa dari sisi pengendara sudah memulai menggunakan bahasa Jawaragam krama karena hubungannya yang sama sekali tidak akrab dengan Yuni dan untuk menunjukkan rasa hormatnya maka pengendara memilih menggunakan bahasa Jawa ragam krama untuk bertanya. Menanggapi hal tersebut, Yuni pun menggunakan bahasa Jawa ragam krama untuk menjawab dengan berkata "Niki sakmeniko njenengan lurus mawon, Pak. Mangke wonten masjid, lha ngajengipun masjid pas meniko dalemipun Pak Bayu”. Dengan demikian, tampak bahwa Yuni dan pengendara sama-sama memilih menggunakan bahasa Jawa ragam krama dengan alasan untuk menjaga etika kesopanan 
ketika berbicara dengan orang yang belum dikenal ataupun dengan orang yang kurang akrab.

Berdasarkan ilustrasi yang ada, dapat diambil simpulan bahwa etika atau norma dalam berbicara dapat memengaruhi seseorang untuk melakukan pilihan kode bahasa. Etika berperan untuk menuntun penutur atau mitra tutur untuk mengambil sikap dalam bertutur pada mitra tuturnya.

\section{Tingkat Keakraban}

Tingkat keakraban merupakan salah satu faktor yang turut memengaruhi pilihan kode bahasa seseorang. Tingkat keakraban masing-masing orang yang berbeda akan menetukan pilihan kode bahasa apa yang tepat digunakan untuk berkomunikasi. Pilihan bahasa yang dipilih oleh penutur dan mitra tutur yang sudah memiliki hubungan akrab dengan mitra tutur yang kurang akrab akan berbeda. Perbedaan tersebut terjadi karena dalam bertutur dengan mitra tutur yang kurang akrab, penutur akan lebih berhati-hati dalam memilih kode bahasa maupun kosakata yang digunakan dalam berkomunikasi. Berbeda ketika penutur berkomunikasi dengan mitra tutur yang sudah akrab, penutur akan lebih leluasa menggunakan kode bahasa. Perbedaan pada bentuk tuturan dengan kondisi penutur yang sudah akrab dan belum akrab dengan mitra tuturnya akan tergambar pada dua percakapan berikut ini.

\section{(6)KONTEKS: TONO BERCERITA KEPADA JOKO MENGENAI

KEINGINANNYA UNTUK MEMANCING DI WADUK GRENENG.}

Tono: "Sibuk terus, Dhe. Gak kober mancing ngeneki lho."

[Sibuk tərUs, Dhe. Ga? kəbər mancIn

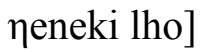

'Sibuk terus, Dhe. Sampai tidak sempat mancing'

Joko : "Sug minggu mangkat piye, Dhe? Tak melok mancing."

[Sug mingu mankat piye, Dhe. Ta? Melo? mancI $\eta]$
'Bagaimana kalau besuk hari minggu berangkat memancing, Dhe? Nanti aku ikut.'

Tono: "Iya, Dhe. Mangkat. Liyane kandani."

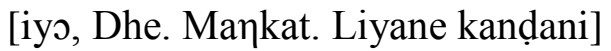
'Iya, Dhe, setuju kalau besuk berangkat mancing. Jangan lupa yang lain diajak juga.'

Joko: "Gampang iku."

[Gampa iku]

'Gampang itu.'

(Data 19)

Tuturan di atas merupakan tuturan yang terjadi dalam interaksi bahasa keluarga muda. Hal Ini terjadi karena mitra tutur Tono adalah Joko yang merupakan anggota keluarga muda. Dalam percakapan tersebut tampak bahwa percakapan yang dilakukan oleh Tono dan Joko sama-sama menggunakan bahasa Jawa ragam ngoko. Pemilihan bahasa Jawa ragam ngoko ini terjadi karena hubungan antara Tono dan Joko sudah sangat akrab. Maka dari itu, untuk berkomunikasi mereka memilih menggunakan bahasa Jawa ragam ngoko. Selain ditandai dari penggunaan bahasa Jawa ragam ngoko, bentuk keakraban mereka juga ditunjukkan dengan sapaan "Dhe" kepada mitra tuturnya. Kata "Dhe" dalam bahasa Jawa merupakan bentuk sederhana dari kata "Pak Dhe" yang berarti 'paman'. Namun, khusus dalam percakapan antara Tono dan Joko, kata "Dhe" yang dimaksud bukanlah merujuk pada bentuk "Pak Dhe" melainkan merupakan sapaan akrab untuk temannya.

Berdasaskan ilustrasi yang telah dipaparkan, dapat diambil simpulan bahwa tingkat keakraban seseorang turut memengaruhi pilihan bahasa dalam berkomunikasi. Percakapan antara seorang yang sudah akrab dengan mitra tuturnya akan tampak lebih lepas dan tidak canggung dalam memilih kosakata dalam berbicara. Berbeda dengan percakapan antara seseorang yang belum begitu akrab dengan mitra tuturnya. Dalam percakapan tersebut akan terlihat adanya batasan-batasan tertentu yang membuat penutur dan mitra tutur harus 
berhati-hati dalam melakukan pilihan bahasa dan melakuan pemilihan kosakata dalam berbicara.

\section{Situasi Tutur}

Situasi tuturan merupakan kondisi yang melatarbelakangi terjadinya suatu tuturan. Dalam interaksi berbahasa keluarga muda di Kecamatan Tunjungan Kabupaten Blora terdapat dua situasi tutur antara penutur dan mitra tutur. Situasi tutur yang dimaksud adalah situasi formal dan situasi non formal. Untuk memberikan gambaran mengenai pengaruh situasi tutur terhadap pilihan kode bahasa, maka dapat dilihat pada contoh tuturan berikut ini.

\section{(7)KONTEKS: LIANTO MEMBERIKAN ARAHAN MENGENAI KEGIATAN KERJA BAKTI YANG AKAN DILAKUKAN}

Lianto :"Assalamualaikumsalam

Warohmatullahi Wabarokatuuh.

Terimakasih atas kehadiran Bapak dan Ibu semua dalam acara rapat bulanan yang telah rutin kita lakukan. Langsung saja pokok bahasan kita malam ini adalah mengenai agenda bersih-bersih kampung seperti yang telah rutin kita lakukan tiap bulannya nggih Pak/ $\mathrm{Bu}$. Nah, untuk agenda bersih-bersih kita kali ini akan dimulai dari depan rumah Mas Irfan ngih Pak. Nanti kita bersihkan itu selokanselokan agar podasi-pondasi di selokan itu tudak mudah rusak. Walau bagaimanapun bangunan yang sudah diusahakan desa kan harus kita rawat ya Pak/ Bu..."

(Data 30)

Lianto merupakan seorang ketua RT yang memiliki usia 25 tahun. Lianto adalah seorang anggota keluarga muda karena tahun lalu dia telah melangsungkan pernikahanya. Oleh karena keadaan tersebut, maka interaksi tutur yang dilakukan lianto dapat digolongkan dalam interaksi tutur keluarga muda. Pada tuturan yang dilakukan Lianto tampak bahwa penutur menggunakan bahasa Indonesia untuk bertutur. Hal ini dilakukan karena penutur tengah memimpin rapat dengan warga. Dengan demikian dapat dikatakan bahwa tuturan tersebut terjadi pada sitauasi formal. Dalam situasi formal, pak RT memilih untuk menggunakan bahasa Indonesia dibanding bahasa Jawa. Hal ini dilakukan untuk menjaga kondisi atau suasana rapat agar tetap terkendali. Selain alasan tersebut, orang-orang memang sering membedakan pola pilihan bahasa yang digunakannya. Dalam situasi formal, masyarakat lebih senang menggunakan kode bahasa Indonesia, sedangkan pada situasi non formal masyarakat memilih untuk menggunakan bahasa Jawa.

Berdasarkan contoh ilustrasi yang telah dipaparkan, tampak bahwa perbedaan situasi tutur dapat mendorong seseorang untuk melakukan pilihan kode bahasa. Pemakaian kode bahasa dalam situasi formal akan berbeda dengan pilihan kode bahasa pada situasi tidak formal. Pilihan bahasa pada situasi tidak formal lebih bebas, luwes, dan tidak terikat pada aturan baku. Berbeda dengan pilihan bahasa dalam situasi formal yang lebih terkesan kaku dan lebih terikat pada aturan baku.

\section{Topik Tuturan}

Perubahan topik pembicaraan juga dapat memberikan pengaruh terhadap pilihan bahasa seseorang. Perubahan topik ketika sedang bertuturkata akan membuat penutur dihadapkan pada suatu pilihan. Apakah nantinya penutur akan tetap mempertahankan kode dasar yang dipakai dalam berkomunikasi dengan mitra tuturnya ataupun memilih untuk menggunakan kode lain yang berbeda dengan kode sebelumnya.

Seperti yang tergambar pada contohcontoh tuturan berikut ini. Akan dipaparkan sebuah tuturan yang didalamnya terdapat perubahan kode bahasa yang disebabkan oleh adanya perubahan topik pembicaraan.

(8)KONTEKS: ATIK BERCERITA KEPADA YUNI MENGENAI MURID YANG MENJENGUK SUAMINYA 
KETIKA SEDANG DIRAWAT DI RUMAH SAKIT

Atik: “Aku ning kana (RS) ya ngono, sak anane jajan tak kon mangani muride pak'e."

[Aku nI jajan ta? kon manani muride pa?e]

'Kemarin ketika sedang di Rumah sakit juga begitu. Ada makanan apa saja saya tawarkan ke muridnya bapak'

Yuni: "Lho do mriki pripun?"

[Lho do mriki pripUn?]

'Lho pada datang ke sini?'

Atik: "Rono. Do marani ning rumah sakit. Alah rasane kudu ndang tak jak balik wae. Pas lagi diperiksa dokter aku langsung ngomong "Alah Dok, udah sehat gini Dok. Boleh pulang ya , Dok?", tapi malah jarene, "Lho ya belum boleh, harus menunggu 24 jam dulu", kata dokter.Aku wis kudu ora betah ae rasane. Ketoke rak wis mari ngono eh. Ternyata iseh urung oleh balik."

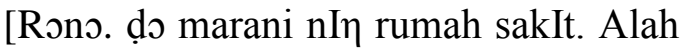
rasane kudu ndaך ta? Ja? balE? Wae pas lagi di periksa dokter aku la "Alah Dok, Udah sehat gini, Dok. Boleh pulang ya, Dok?", tapi malah jarene, "Lho ya belum boleh, harus menunggu 24 Jam dulu", kata dokter. Aku wIs kudu ora bətah ae rasane.

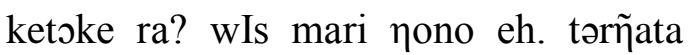
iseh uruך oleh balik.]

'Kesana. Datang ke rumah sakit. Aduh rasanya itu ingin segera saya ajak pulang saja. ketika ada dokter yang periksa itu saya langsung minta izin "sepertinya sudah sehat begini, Dok. Sudah boleh pulang ya, Dok?", tapi ternyata dokternya malah bilang, "Lho ya belum boleh, harus menunggu 24 jam dulu", kata dokter. Saya itu sebenarnya sudah tidak betah disana. Kelihatannya kan sudah sembuh begitu, tapi ternyata tetap belum boleh pulang.'

(Data 35)
Pada ilustrasi (35) tampak bahwa tuturan Atik mengalami perubahan topik. Awalnya Atik menceritakan tentang muridmurid suaminya yang datang ke rumah sakit untuk menjenguk. Selanjutnya Atik pindah topik dan bercerita tentang dirinya yang tidak tahan berlama-lama di rumah sakit. Dan setelah itu pindah topik lagi untuk menceritakan percakapannya dengan dokter ketika di rumah sakit.

Pada peralihan topik pertama ke topik kedua tampak bahwa Atik tetap mempertahankan pilihan kode pertama. Peralihan kode bahasa mulai terlihat ketika Atik bercerita tentang percapannya dengan dokter ketika di rumah sakit. Ini tampak pada tuturan Atik yang berbunyi "Pas lagi diperiksa dokter aku langsung ngomong "Alah Dok, udah sehat gini Dok. Boleh pulang ya , Dok?", tapi malah jarene, "Lho ya belum boleh, harus menunggu 24 jam dulu", kata dokter.Aku wis kudu ora betah ae rasane. Ketoke rak wis mari ngono eh. Ternyata iseh urung oleh balik".Atik memilih bercerita manggunakan bahasa Indonesia ketika bercerita tentang dialognya dengan dokter. Dengan demikian ilustrasi pada tuturan ini menunjukkan bahwa pergantian topik tuturan akan mempenaruhi perubahan pilihan bahasa seseorang.

\section{Lokasi Tuturan}

Lokasi tuturan merupakan tempat dimana suatu tuturan itu terjadi. Lokasi tuturan adalah salah satu faktor yang turut memengaruhi penyebab terjadinya pilihan bahasa. Dalam praktiknya, disadari ataupun tidak, penutur akan secara serta merta menyenyuaikan pilihan kode bahasa dengan lokasi tempat dimana ia melakukan tindak tutur. Misalkan saja, tuturan seseorang yang sedang berada di pasar akan berbeda dengan tuturan seseorang yang sedang berada di Masjid. Hal ini bisa saja terjadi karena setiap manusia pasti memiliki naluri untuk melakukan penyesuaian diri dengan tempat yang didatangi. Begitupun dengan penggunaan bahasa di tempat-tempat tertentu, secara langsung seseorang akan 
menyesuaikan pilihan kode bahasanya dengan tempat yang sedang mereka singgahi. Berikut ini contoh tuturan untuk memperjelas gambaran mengenai lokasi tuturan yang dapat memengaruhi pilihan bahasa seseorang.

(9)KONTEKS: YUNITA, YATI, DAN NIA SEDANG BERBINCANG MENGENAI KELANGKAAN BENSIN YANG ADA DI DAERAH TUNJUNGAN.

Yati: "Ndek bengi antri neh gak nduk bensine?"

[ndE? bəๆI antrI nEh ga? ndU? bEnsine]

'tadi malam beli bensinnya antre dulu tidak'

Nia: “Telas mbah, mpun telas."

[Təlas Mbah, mpUn təlas]

'Habis Nek, sudah habis,

Yati: "Lha ya, Pak ne Mut ora nganti antre.

Biasane pakne Kiki gelem antrI, saiki wonge emoh."

[Lha yo, Pak ne Mut ora nantI antre.

Biasane Pakne Kiki gələm antre, saikI woๆe əmoh]

'Iya, bapaknya Mut tidak sampai ikut antre. Biasanya kan yang antre bensin bapaknya kiki, sekarang sudah tidak mau.'

Yunita : "Ora sido mundak kok."

[ora sido munda? ko?]

'Tidak jadi naik kok.'

Yati :"Gak sido?"

[ga? sIdo]

'Tidak jadi'

Nia : "Dereng sios mundak."

[DErEๆ sios munda?]

'Belum jadi naik'

Yunita : "Lha ya, marai iseh simpang siur." [Lha yo, marai isch simpan siur]

'Lha iya, soalnya masih simpang siur'

(Data 37)

Dalam percakapan (37) tampak bahwa penutur dan mitra tutur sama-sama menggunakan bahasa Jawa untuk berkomunikasi. Hal ini dilakukan karena penutur dan mitra tutur sama-sama terbiasa menggunakan bahasa Jawa untuk berkomunikasi sehari-hari. Selain untuk alasan kepraktisan, pilihan menggunakan bahasa Jawa juga dipengaruhi oleh lokasi terjadinya tuturan. Pasar merupakan tempat bertemunya banyak orang dan sebagian orang yang berinteraksi di pasar menggunakan bahasa Jawa. Oleh karena itu, penutur dan mitra tutur memilih menggunakan bahasa Jawa dalam tuturan mereka.

Tuturan yang dilakukan oleh Yunita, Nia, dan Yati dapat dikategorikan sebagai interaksi keluarga muda karena dalam tuturan tersebut melibatkan Yunita yang merupakan seorang perempuan berusia 23 tahun yang sudah menikah. Dengan demikian, interaksi tutur yang dilakukan Yunita dapat dikategorikan sebagai interaksi tutur anggota keluarga muda.

Berdasarkan ilustrasi yang dipaparkan, tampak bahwa lokasi turut memengaruhi pilihan bahasa yang digunakan penutur. Pilihan bahasa penutur akan berbeda disesuaikan dengan dimana tempat mereka sedang bertutur kata.

\section{Simpulan}

Karakteristik bahasa keluarga muda berdasarkan perbedaan gender di Kecamatan TunjunganKabupaten Blora dapat dilihat dari karakteristik penutur laki-laki dan perempuan. Karakteristik bahasa laki-laki lebih didasarkan pada sifat maskulin, yaitu lebih agresif, menguasai pembicaraan, berani, dan garang. Adapun karakteristik bahasa perempuan bersifat kurang tegas, tidak mengutarakan secara jelas (lebih sering memakai kata kiasan), dan berhati-hati dalam mengucapkan sesuatu. Selain itu, perempuan juga lebih sering membicarakan orang lain, mudah bersimpati, dan menceritakan hubungan sosialnya dengan orang lain.

Faktor yang memengaruhi pemilihan bahasa dalam interaksi keluarga muda di Kecamatan Tunjungan Kabupaten Blora selain faktor perbedaan gender adalah etika/norma sosial, tingkat keakraban, situasi tutur, topik tuturan, dan lokasi tuturan. 
Berdasarkan simpulan yang telah dipaparkan, peneliti menyarankan kepada pemerhati bahasa untuk melakukan penelitian lanjutan karena fenomena kebahasaan yang terjadi di Kecamatan Tunjungan Kabupaten Blora cukup unik. Selain itu terdapat beberapa kosakata khas yang hanya dapat ditemukan pada tuturan masyarakat yang tinggal di Kecamatan Tunjungan Kabupaten Blora. Dengan demikian, penelitian lanjutan sangat disarankan untuk dilakukan.

\section{Daftar Pustaka}

Alwasilah, A. Chaedar. 1985. Pengantar Sosiologi Bahasa. Bandung: Angkasa.

Chaer, Abdul dan Leonie Agustina. 2004.Sosiolinguistik Perkenalan Awal. Jakarta: Rineka Cipta.

Gerungan, W. A. 1996. Psikologi Sosial. Bandung. Eresco.

Handayani, Trisakti dan Sugiarti. 2008. Konsep dan Teknik Penelitian Gender. Malang: UMM press.
Keraf, Gorys. 2007. Diksi dan Gaya Bahasa. Jakarta: Gramedia.

Koentjaraningrat. 1994. Kebudayaan, Mentalitas dan Pembangunan. Jakarta: Gramedia Pustaka Utama.

Kridalaksana, Harimurti. 1982. Kamus Linguistik. Jakarta: Gramedia.

Mahsun. 2007. Metode Penelitian Bahasa: Tahapan Strategi, Metode, dan Tekniknya. Jakarta: Raja Grafindo Persada.

Moleong, Lexy. 2004. Metodoligi Penelitian Kualitatif. Bandung: PT Remaja Rosdakarya.

Sudaryanto. 1993. Metode dan Aneka Teknik Analisis Bahasa: Pengantar Penelitian Wahana Kebudayaan Secara Linguistik. Yogyakarta: Duta Wacana.

Sumarsono. 2004. Sosiolinguistik. Yogyakarta. SABDA Lembaga Studi Agama dan Perdamaian Kerjasama Pustaka Pelajar.

Suwito. 1985. Sosiolinguistik Pengantar Awal. Solo: Henary Offset. 